\title{
Configurações
}

Revista de sociologia

Sociedade, Autoridade e Pós-memórias

\section{Sheila Khan, Portugal a lápis de cor. A sul de uma pós-colonialidade. Coimbra: Almedina, 2015}

Sandra I. Sousa

\section{OpenEdition}

\section{Journals}

\section{Edição electrónica}

URL: http://journals.openedition.org/configuracoes/3295

DOI: 10.4000/configuracoes.3295

ISSN: 2182-7419

\section{Editora}

Centro de Investigação em Ciências Sociais

Edição impressa

Data de publição: 27 Junho 2016

Paginação: 259-261

ISSN: 1646-5075

\section{Refêrencia eletrónica}

Sandra I. Sousa, "Sheila Khan, Portugal a lápis de cor. A sul de uma pós-colonialidade. Coimbra: Almedina, 2015 », Configurações [Online], 17 | 2016, posto online no dia 30 junho 2016, consultado o 23 abril 2019. URL : http://journals.openedition.org/configuracoes/3295 ; DOI : 10.4000/

configuracoes.3295 


\section{Sheila Khan, Portugal a lápis de cor. A sul de uma pós-colonialidade. Coimbra: Almedina, 2015}

SANDRAI. SOUSA*

University of Central Florida

Abrindo com um prefácio cativante e perspicaz de Paulo de Medeiros, Portugal a lápis de cor. A Sul de uma pós-colonialidade é uma importante contribuição para um dos campos que recentemente se tem configurado como dos mais dinâmicos na academia portuguesa, o dos estudos pós-coloniais. Sentindo, no entanto, uma lacuna na forma como a análise pós-colonial tem vindo a ser feita em Portugal, a autora lança-se à complexa tarefa de pensar sociologicamente um país que, como ela própria afirma, é um "grande puzzle histórico" em consequência da sua condição outrora imperial e colonizadora. Deva-se afirmar de imediato que Portugal a lápis de cor é um livro de indispensável leitura para aqueles que pretendem entender o passado imperial e colonial português e a forma como este legado se reflete num presente pressupostamente pós-colonial e imperial. Digo "pressupostamente" pois fica óbvio da leitura de Khan que Portugal é um país à deriva entre o que foi e o que pretende ser (não se sabendo muito bem o que pretende ser).

Partindo dos factos irrefutáveis de que, após o processo de descolonização das suas possessões africanas, Portugal acolheu no seu território "outros rostos, outras vidas com outras vivências, outras narrativas e outros modos de estar e ser" e que "estas outras presenças humanas permanecem, ainda, socialmente ignoradas e marginalizadas não obstante a existência de uma profilaxia politicamente correcta de Portugal como país 'luso-tropicalista' e, como tal, multicultural," Khan lança as pertinentes questões: porque continuam a persistir em Portugal ausências e silêncios, ou seja, porque não existe a incorporação das vozes dos Outros nos discursos oficiais e não oficiais?; que aprendizagens retirou Portugal da sua experiência colonial para posteriormente se iniciar como nação pós-colonial? Numa frase, porque nada (ou muito pouco) parece ter mudado em termos de atitude em relação ao Outro que, como é enfatizado pela autora ao longo da obra, vive mesmo aqui ao lado?

Tendo como foco principal "o Sul humano representado por todos aqueles que a pós-colonialidade portuguesa - sejam os africanos, os imigrantes, sejam os refugiados - insiste em esquecer” e, em particular, a comunidade moçambicana, Khan baseia-se na ferramenta metodológica a sociologia das ausências desenvolvida por Boaventura de Sousa Santos, expandindo-a para

\footnotetext{
* Professora Auxiliar da University of Central Florida. Email. sandraasousa@gmail.com.
} 
uma sociologia pós-colonial das ausências. O objetivo fundamental desta abordagem passa pela necessidade de refutar e desafiar a hegemonia ocidental ao mesmo tempo que pretende "descolonizar" a hegemonia do pensamento ocidental.

Ao longo de cinco capítulos em que o leitor segue uma linha de pensamento concisa e bem estruturada, a autora problematiza a questão da centralidade de Portugal no seu passado de país imperial e colonizador e a sua permanente tendência para se imaginar como centro desde a perda das colónias africanas e entrada para a comunidade europeia até ao presente. Para tal, Khan coloca em confronto duas presenças ou tendências que designa por pós-colonialismo do quotidiano e pós-colonialismo de investigação/reflexão. O que está aqui em causa é o suposto desfasamento ou, se quisermos, fronteira, entre o que se faz e pensa no mundo académico e as experiências vividas e sentidas pelas populações africanas em Portugal no seu dia a dia. É talvez no confrontar destas duas perceções que consiste a maior originalidade desta obra e do pensamento da autora. No sentido de chamar a atenção para essas outras vozes invisíveis que coabitam lado a lado com a população portuguesa e que esta continua sistematicamente a ignorar como não fazendo parte do mesmo tecido social, a autora confronta-nos com essas mesmas vozes, dando-lhes a oportunidade de serem ouvidas.

Existe neste livro a urgência e a extrema necessidade de reclamar um espaço para estas comunidades que vivem na periferia de uma sociedade que se diz democrática, igualitária e multicultural. É tempo de se passar da teoria para a prática e Khan faz esse apelo numa voz de humildade, firmeza e esperança, pensando a teoria pós-colonial elaborada por diversos teóricos académicos vis-à-vis narrativas ficcionais e autobiográficas, estilhaçando barreiras e confrontando experiências. É apenas neste confronto que Portugal se poderá libertar do seu défice que, segundo a autora, "resulta de uma certa tendência portuguesa de não saber encarar e aceitar o Outro como seu próximo e, de certo modo, como sua parcela histórica, social e cultural.” Este défice advém ainda de uma débil revisitação do seu passado e, mais problemático quiçá, de uma perda ou aniquilação de memória. Esta revisitação das memórias e das narrativas, que não se inserem nos manuais de história, nos registos oficiais e nos anais do país, é essencial para que Portugal se reconfigure como espaço de liberdade de pensamento, ação e voz, como espaço de pertença e não de ausência. Como invoca a autora, "Hoje, mais do que nunca, pensar a pós-colonialidade como uma postura, uma opção moral, tem de inevitavelmente assumir-se como um compromisso com a História desta nação (...). Os narradores desta História terão de ser também os Outros, aqueles ainda remetidos ao esquecimento e à invisibilidade sociais”.

Portugal a lápis de cor é um livro de complexidade temática, no entanto, como todos os excelentes pensadores, Khan sabe converter a complexidade em 
simplicidade usando uma linguagem simples e livre dos jargões académicos que na maioria das vezes criam barreiras e muros culturais entre a Academia e o público em geral. Esta é sem dúvida uma obra de mérito igualmente por essa razão: a autora é capaz na prática de quebrar as barreiras que são o cerne do objetivo do seu livro. Portugal a lápis de cor é de leitura aprazível, acessível e recomendável a todos os que se pretendem tornar cidadãos conscientes de um país que se requer também ele consciente. Tal só poderá ser feito a partir da "partilha e realização de um diálogo franco e de um reconhecimento de outros saberes, outras visões, outras percepções”, ou seja, rejeitando qualquer forma de hegemonia. 
